\title{
Staphylococcus aureus in poultry, with special emphasis on methicillin-resistant strain infection: A comprehensive review from one health perspective
}

\author{
Wafaa A. Abd El-Ghany (D) \\ Department of Poultry Diseases, Faculty of Veterinary Medicine, Cairo University, Giza 12211, Egypt. \\ Corresponding author: Wafaa A. Abd El-Ghany, e-mail: wafaa.ghany@yahoo.com \\ Received: 27-07-2021, Accepted: 18-10-2021, Published online: 17-12-2021
}

doi: www.doi.org/10.14202/IJOH.2021.257-267 How to cite this article: Abd El-Ghany WA (2021) Staphylococcus aureus in poultry, with special emphasis on methicillin-resistant strain infection: A comprehensive review from one health perspective, Int. J. One Health, 7(2): 257-267.

\begin{abstract}
Staphylococcus aureus is a Gram-positive coccus normally present on the skin and internal organs of animals, birds, and humans. Under certain conditions, $S$. aureus could produce septicemia and affection of the skin, joints, and heart, as well as sepsis and death. The pathogenicity of $S$. aureus is associated with the presence of some virulent surface proteins and the production of some virulent toxins and enzymes. This pathogen is considered one of the most important and worldwide foodborne causes as it is incriminated in most cases of food poisoning. The hazardous use of antibiotics in the veterinary field leads to the development of multidrug-resistant $S$. aureus strains that can be transmitted to humans. The incidence of methicillin-resistant $S$. aureus (MRSA) strains has increased globally. These resistant strains have been detected in live animals, poultry, and humans. In addition, retail animal products, especially those of avian origin, are considered the main source of MRSA strains that can be easily transmitted to humans. MRSA infection is regarded as nosocomial or occupational. Humans get infected with MRSA strains through improper handling or preparation of contaminated animals or poultry carcasses or improper cooking with contaminated meat. Live birds also can transmit MRSA to close-contact workers in poultry farms. Transmission of MRSA infection in hospitals is from an infected individual to a healthy one. Prevention and control of MRSA are based on the application of hygienic measures in farms as well as proper processing, handling, and cooking of retail poultry products. The cooperation between veterinary and human practitioners is a must to avoid the possibility of zoonotic transmission. Accordingly, this review focused on the sources and transmission of MRSA infection, virulence and resistance factors, incidence and prevalence in poultry and different products, antibiotic resistance, and prevention and control strategies.
\end{abstract}

Keywords: chickens, food poisoning, humans, methicillin-resistant Staphylococci, zoonosis.

\section{Introduction}

Staphylococcus aureus is regarded as an opportunistic and commensal organism of animals, birds, and humans. It may reside asymptomatically on the skin and in the nose of animals [1]. However, under certain circumstances, $S$. aureus causes skin and soft-tissue infection, osteomyelitis, endocarditis, sepsis, and death [2]. Like in humans and other animals, $S$. aureus could be isolated as a normal microflora from poultry skin, feathers, and respiratory and intestinal tracts $[3,4]$. Nevertheless, this pathogen could be associated with some disease conditions, such as dermatitis, arthritis, osteomyelitis, synovitis, tenosynovitis, femoral head necrosis, bumble-foot, and omphalitis [5]. The severity of lesions is linked to the presence of some virulence factors, such as enzymes and toxins [6].

$S$. aureus is recognized as the third most important worldwide cause of foodborne infections [7].

Copyright: Abd El-Ghany. This article is an open access article distributed under the terms of the Creative Commons Attribution 4.0 International License (http://creativecommons.org/licenses/ by/4.0/), which permits unrestricted use, distribution, and reproduction in any medium, provided you give appropriate credit to the original author(s) and the source, provide a link to the Creative Commons license, and indicate if changes were made. The Creative Commons Public Domain Dedication waiver (http:// creativecommons.org/ publicdomain/zero/1.0/) applies to the data made available in this article, unless otherwise stated.
A concentration of $10^{5}$ to $10^{8}$ colony-forming units of $S$. aureus $/ \mathrm{g}$ in food can cause food poisoning in humans [8]. Staphylococcal food poisoning is associated with the secretion of enterotoxins produced in the exponential phase of pathogen growth [9]. Enterotoxigenic $S$. aureus strains can contaminate food, causing foodborne poisoning and toxic shock syndrome $[10,11]$.

Antibiotic-resistant bacteria in animals are of growing concern because of their possible role in transmission to humans as foodborne pathogens [12]. There is no doubt that the extensive usage of antimicrobials in the poultry industry enhanced the ability of $S$. aureus to acquire many resistance genes and thus become more virulent [13]. These resistance genes and the resistant bacteria could be transferred to humans through meat consumption and in sequence threaten the effectiveness of prevention and control strategies [14]. Dissemination of antimicrobial resistance among Staphylococcus strains is probably due to variations in DNA sequences and horizontal transfer of resistance genes [15].

Methicillin-resistant $S$. aureus (MRSA) strains have been increasingly reported as emerging pathogenic strains that cause great problems in veterinary medicine. The term "MRSA" is related to nonsusceptibility to at least one of the antimicrobials in three or 
more categories and whose resistance to oxacillin or cefoxitin predicts nonsusceptibility to most categories of $\beta$-lactam antimicrobials [16]. About $96 \%$ of $S$. aureus strains are resistant to at least one antibiotic, whereas $32 \%$ are resistant to multiple antimicrobial classes [17]. The World Health Organization (WHO) has classified MRSA strains as "high priority 2 pathogens," due to their great threat to the health of both humans and animals. The first identification of MRSA strains was in 1961 in England, after which they have emerged worldwide [18]. Since the 1990s, MRSA has been regarded as a nosocomial or community-associated pathogen and has become a significant public health and worldwide zoonotic problem [19]. Resistant MRSA strains represent a great threat to consumer health [20-22].

In poultry, MRSA strains were isolated for the $1^{\text {st }}$ time from arthritis cases in South Korea; then, different strains have been isolated from live birds and retail poultry products [23]. The presence of MRSA in live poultry has been reported and has highlighted the increase in the antibiotic resistance rate, especially in recently isolated strains [17]. Different kinds of animal meat as well as frozen and raw chickens and turkeys show the presence of MRSA [21,24]. However, chicken meat is considered an important reservoir for MRSA [25].

Therefore, this review focused on the sources and transmission of MRSA infection, virulence and resistance factors, incidence and prevalence in poultry and different products, antibiotic resistance, and prevention and control strategies.

\section{Sources and Transmission of MRSA Infection}

MRSA is rapidly disseminated among animals, humans, and the environment. It can spread through water, air, food, and contaminated surfaces and transmits through direct contact between animals and humans [26-28]. Livestock-associated MRSA poses a zoonotic risk to humans, especially close-contact workers [29]. The horizontal route of transmission among animals or humans may occur.

Avian MRSA strains can infect birds and show zoonotic importance and risk for poultry handlers and processors [30,31]. Poor hygienic practice during the processing of foodstuff as chicken meat results in contamination with bacterial toxins. However, improper handling by food handlers, improper meat storage, inadequate food cooking, and improper food preparation using contaminated water are also sources of food contamination with MRSA [32,33]. Chicken meat could be contaminated with MRSA during bird slaughtering or meat preparation [20,21]. Unlike other types of bacteria, $S$. aureus, especially MRSA strains, has shown relative resistance to the adverse effects of freezing conditions [34].

Transmission of MRSA from poultry to humans may occur through ingestion of contaminated meat or direct contact with live bird or their droppings [31]. In an Algerian study, S. aureus and MRSA isolated from avian origin were more resistant to $\beta$-lactam antibiotics, especially penicillin and oxacillin, than bovine origin [35]. The study suggested transmission of MRSA from poultry to bovine and humans with great difficulties in treatment trials. Poultry litter is another source of $S$. aureus infection in poultry farms [36-38].

At healthcare units, discharge of infected patients with MRSA may be an important source of infection to healthy contact individuals, such as health workers; consequently, they may transmit the infection to noninfected persons. In addition, there is a possibility of transmission of MRSA from infected humans to animals (anthroponosis) or from infected animals to contact humans (zoonosis) after handling of animals and contaminated equipment or products [31].

\section{Virulence and Resistance Factors}

S. aureus is a Gram-positive, nonmotile, and non-spore-forming coccus. This organism can grow from $15^{\circ} \mathrm{C}$ to $45^{\circ} \mathrm{C}$ and requires higher sodium chloride concentrations (10\%) [39]. However, at room temperature, $S$. aureus could multiply quickly and release toxins, producing illness.

Multidrug-resistant (MDR) S. aureus strains are resistant to three or more classes of antibiotics, and they show difficulties in the treatment [40]. Unfortunately, the incidence of MDR $S$. aureus strains has increased due to the hazardous use of antimicrobials in the prophylaxis and treatment of diseases in either animals or humans. Multiple cross-resistance has been detected in MRSA strains in food products of chicken and turkey origins [41]. Lately, MDR $S$. aureus isolates have been reported in food poisoning outbreaks after consumption of contaminated food products [42].

The ability of $S$. aureus strains to show multiple resistances to antibiotics might be due to the production of an exopolysaccharide barrier [43] and carriage of variable MDR genes on plasmids that could be exchanged and spread to other Staphylococcus species [44]. Therefore, this resistance could normally be produced by horizontal gene transfer or mutation and selection [45].

There are some important cell-surface proteins on $S$. aureus that mediate the virulence and adhesion of the organism to host cells. These proteins include an elastin-binding protein and clumping factors $\mathrm{A}$ and $\mathrm{B}$ (clfA and clfB genes) [46,47], matrix adhesion proteins, and extracellular matrix fibrinogen and collagen proteins [48]. Besides, protein A (spa gene) is a multifunctional surface protein located on a fragment crystallizable portion of immunoglobulin $\mathrm{G}(\operatorname{IgG})$. This protein produces immune evasion and hinders the antibody-mediated immune clearance of the pathogen, so it can act as a superantigen of B cells [48]. Accordingly, protein A antagonizes the phagocytosis of opsonized bacteria through binding with IgG [49].

Numerous genetic elements encode virulence and resistance of MRSA to antimicrobials [50]. 
The synthesis of penicillin-binding protein (PBP), modified PBP2a [51], PBP2' [52], or MRSAPBP [53] is considered the most important, if not the only, means of conferring high resistance to $\beta$-lactams. Moreover, the absence of resistance to methicillin in $S$. aureus strains is frequently associated with the absence of PBP [54]. The production of PBP2a with decreasing susceptibility to $\beta$-lactam antibiotics in MRSA is encoded by the mecA gene $[55,56]$, which carries insertion sites for genetic elements that facilitate the gain of resistance determinants to other antimicrobials [57]. Methicillin is penicillin-resistant to penicillinase, and $S$. aureus strains become resistant to methicillin by acquiring the mecA gene [58]. This gene is found in staphylococcal cassette chromosome mec ( $\mathrm{SCCmec}$ ), responsible for resistance to several antibiotics [59]. There are seven main variants of SCCmec (Types I-VII). MDR S. aureus strains associated with the $m e c A$ gene were detected in retail meat products [60], chicken meat and giblets [14], and ready-to-eat meat products [61]. In addition, the $\mathrm{mecC}$ gene showed verified $70 \%$ homology to the methicillin resistance $m e c A$ gene [62].

In Bangladesh, Islam et al. [63] found that more than $74 \%$ of $S$. aureus isolates collected from readyto-eat food and processed meat products harbored enterotoxin genes with distribution percentages of $26 \%, 11 \%, 49 \%$, and $13 \%$ for sea, seb, sec, and sed genes, respectively. seb, sec, and see genes can resist the hydrolysis process produced by gastric and jejunal enzymes, and they are heat stable at $100^{\circ} \mathrm{C}$ for $30 \mathrm{~min}$ [64]. This explains why food poisoning caused by $S$. aureus is a leading worldwide cause of foodborne bacterial intoxication [65].

$\gamma$-Hemolysin ( $h l g$ gene) is considered one of the most important virulent genes of Staphylococcus as it is responsible for pore formation in red blood cells after binding of acting proteins $h \lg \mathrm{A}$ and $h \lg \mathrm{B}$ [66]. Coagulase (coa gene) is another virulence marker of Staphylococcus. Coagulase helps in fibrin formation surrounding staphylococcal abscess, which helps in localized infection and protects bacteria from the phagocytosis process [67].

Several toxin gene groups as enterotoxins (sea, seb, sec, sed, see, seg, seh, and sei), toxic shock syndrome toxin 1 (tst), exfoliative toxins (eta and $a t b$ ), leukocidins (lukE-lukD and $l u k \mathrm{M})$, Panton-Valentine leukocidin (lukS-lukF), and hemolysins (hla, hlb, and $h l d$ ) were used to detect MRSA from retail chicken and turkey meat in Oklahoma [68].

\section{Incidence and Prevalence in Poultry and Different Products}

\section{Poultry farms}

Live birds are regarded as an important reservoir for pathogenic $S$. aureus strains. For example, Mamza et al. [69] isolated $S$. aureus strains at a rate of $52.5 \%$ from apparently healthy and diseased chickens, whereas
Suleiman et al. [70] found coagulase-positive $S$. aureus in $54 \%$ of apparently healthy chicken samples. In addition, Nworie et al. [71] showed that $76 \%$ (247 of 325$)$ of $S$. aureus isolated from nasal and cloacal swabs of chickens were from poultry, and the prevalence rates of the organism were $6.1 \%$ and $15.3 \%$ in broilers and layers, respectively. However, $S$. aureus in $90 \%$ of nasal and cloacal swabs of broilers were detected in Egypt [72]. Two hundred and fifty broiler chicken samples, including nasal, tracheal, and cloacal swabs, hock joint, and liver, were collected from apparently healthy and diseased birds for isolation of S. aureus [73]. Results showed the presence of 157 Staphylococcus isolates with an isolation rate of $62.8 \%$, of which $81(55.9 \%)$ were coagulase-positive and 76 (48.4\%) were coagulase-negative. Recently, Bounar-Kechih et al. [35] collected 8375 chicken samples (1875 from laying hens and 6500 from broiler chickens) in the northern region of Algeria between 2009 and 2014. They demonstrated that the prevalence rates of $S$. aureus were $42 \%$ and $12 \%$ in laying hens and broilers, respectively.

Based on phenotypic and genotypic characterizations of MRSA in poultry farms, live poultry are frequently carrying MRSA [74-76]. Cloacal and nasal swabs of 75 broilers and 50 laying hens were collected from poultry flocks in Belgium. Results showed detection of 15 MRSA strains from broilers, but no strain was obtained from laying hens [77]. In poultry farms in China, MRSA strains were reported with variable prevalence rates from one farm to another according to antibiotic usage load [78]. Moreover, MRSA strains were found in 11 of $250(4.4 \%)$ pooled pharyngeal swabs of broilers in the Netherlands [79]. A cross-sectional study of Friese et al. [80] revealed detection of MRSA in air samples of poultry farms ( 7 of $9,77.8 \%$ ) and $50-54 \%$ of broiler samples and $62-77 \%$ of turkey samples. In Nigeria, Adeyeye and Adewale [30] demonstrated MRSA strains in 90 of 100 cloacal swabs of 6-weekold diarrheic broiler chickens at an incidence rate of $90 \%$. However, the percentage carriage of MRSA in poultry was $6.1 \%$, and all MRSA strains were MDR. A strong correlation between methicillin resistance and cross-resistance to $\beta$-lactam antimicrobials was detected in Qena Province, Egypt [81]. Besides, Abd El Tawab et al. [5] characterized MRSA strains in $66 \%$ of the samples from bumble-foot and skin of chickens. MRSA prevalence was $57 \%$ in laying hens and 50\% in broiler chickens in Algeria [35]. Recently, Benrabia et al. [82] detected MRSA strains in 252 of 4248 (5.9\%) nasal swabs, representing 654 breeding hens, 838 laying hens, 1614 broiler chickens, and 1142 turkeys [82].

\section{Poultry products}

Meat products may contain MRSA and play an important role in human food poisoning infection [83]. The prevalence rate of MRSA isolated 
from raw retail meat products ranged from $<1 \%$ in the Netherlands [84] to $11.9 \%$ in Korea [85]. The presence of MRSA in commercial raw poultry meat was recorded in 2004 in Japan, where two mecA-positive MRSA strains were detected in 444 raw poultry meat samples [23]. Of 150 calf/lamb meat and chicken part samples, 80 (including 26 isolates of poultry origin) were $S$. aureus strains, the overall methicillin resistance rate of $S$. aureus strains was $67.5 \%$, and the methicillin resistance was $76.4 \%$ and $55.5 \%$ for chicken carcass and chicken giblets, respectively [86]. In the United States, of 136 poultry meat samples, $47 \%$ were contaminated with $S$. aureus and $52 \%$ of the isolates were demonstrated as MRSA [17]. However, $2(1.2 \%)$ MRSA strains were also detected in 114 retail chilled chickens and 53 turkeys [68]. In 2012 in Qena Province, $44 \%$ (11 of 25), 52\% (13 of 25), 40\% (10 of 25 ), $24 \%$ (6 of 25 ), and $44 \%$ (11 of 25 ) of MRSA strains were identified from whole chicken carcasses, chicken portions, chicken luncheon, chicken sausages, and chicken burgers, respectively [81]. Therefore, contaminated poultry meat or products are considered one of the important sources of transmission of MRSA to humans, probably due to unhygienic poultry slaughterhouses and food preparation establishments. In England, 9 of $61(7.3 \%)$ MRSA strains were isolated from chicken and turkey meat samples [87], whereas MRSA strains were found in 4\% of 102 chicken meat samples in Denmark [88]. Lately, in Northern Algeria, the prevalence of MRSA in laying and broiler chickens in slaughterhouses was demonstrated in $23.9 \%$ and $6.4 \%$ of the samples, respectively [35]. Recent studies revealed the presence of MRSA in raw and frozen chicken meat in different countries worldwide, such as China [20], Bangladesh [89,90], Hong Kong [22], and Egypt [21,91]. Interestingly, MRSA strains were also isolated from quail meat [92-94]. Recently, Saadati et al. [95] found that 2 of $70(2.86 \%)$ quail samples were MRSA strains in shopping centers of Iran.

Table eggs also are incriminated in foodborne infection with $S$. aureus. Stepień-Pyśniak et al. [96] isolated $S$. aureus from eggs at a rate of $45.7 \%$, of which $2.5 \%, 38.7 \%$, and $58.8 \%$ were found in the white, yolk, and on shell, respectively. Moreover, coagulase-positive $S$. aureus strains were isolated from eggs at a prevalence rate of $40 \%$ and an isolation rate of $29(14.5 \%), 15(7.5 \%)$, and $36(18 \%)$ from shell, contents, and both shell and contents, respectively [64]. In the latest study of Kemal et al. [97], $93(27.8 \%) S$. aureus strains were demonstrated in 335 egg samples, with $63(18.8 \%)$ from shell and $30(8.9 \%)$ from contents.

\section{Infection of humans}

As a result of the spread of MRSA beyond hospital premises, the epidemiology of MRSA showed worldwide changes [98]. Nowadays, MRSA is considered a community pathogen in many parts of the world [99]. Variable incidence and prevalence of
MRSA have been reported in human clinics [100,101]. Hafiz et al. [102] stated that the prevalence of MRSA could be $\sim 60 \%$. A relatively high prevalence of MRSA infections (up to $30 \%$ ) has been demonstrated in African countries, such as Nigeria, Kenya, and Cameroon, whereas it was $<10 \%$ in Tunisia [103]. In Nigeria, 20.2\% [104], 41.5\% [105], 48.78\% [106], and 50\% [107] of S. aureus strains showed methicillin resistance among clinical patient samples. In 2001 in Algeria, the frequency of MRSA infection was $14 \%$, but this percentage recently showed a significant increase to $40 \%$ in hospitals $[108,109]$. In northwest Algeria, vancomycin resistance of MRSA has been detected as $54 \%$ in poultry and $1.8 \%$ in humans [110].

The European Centre for Disease Prevention and Control [111] estimated that MRSA strains caused 17,000 blood infections and 5400 deaths in 2007 in Europe and 84,000 invasive infections and 11,000 deaths in 2011 in the United States [112]. In Hong Kong, 32\% of mortality from MRSA bacteremia cases has been reported [113]. Moreover, Wu et al. [20] estimated that $S$. aureus, particularly MRSA, is incriminated in 241,000 foodborne illness cases each year in the United States. In China, $S$. aureus is responsible for $12.5 \%$ of foodborne bacterial outbreaks, and it is regarded as the third most frequent food poisoning pathogen after Vibrio parahaemolyticus (27.8\%) and Salmonella (23.1\%) [114].

The emergence of MRSA in human infections is significantly related to the high prevalence in poultry meat, which is considered a great health hazard for consumers [84]. Recently, MRSA strains have gained deep attention due to the possibility of zoonotic transmission to humans from contaminated retail meat or food chain $[20,21,115]$. In addition, MRSA has been identified as a key pathogen in nosocomial (hospital or community) and livestock-associated infections [116]. The molecular epidemiology of $S$. aureus and MRSA from food animals and occupationally exposed humans have been also reported [117-120]. Tested food, including poultry meat in hospitals, showed the presence of MRSA with a total prevalence of $7.62 \%$; besides, a high prevalence of human and poultry-based biotypes was seen in hospital food samples [121]. S. aureus, particularly MRSA, is a leading cause of food poisoning and other illness of humans, such as postoperative wound infections, septicemia, and pneumonia $[122,123]$. MRSA is a major cause of global human morbidity and mortality [124,125]. In developing countries, it has been estimated that contamination of chicken meat or related products with MRSA is one of the most important causes of human digestive problems with high morbidity and mortality [22].

Infection of humans with MRSA strains may also occur through direct contact with infected live birds in farms. In Nigeria, MRSA strains were isolated from nasal swabs of 25 close-contact workers, showing symptoms of cough, and from five attendants 
without signs in infected broiler chicken farm with an incidence rate of $83.3 \%$ [31], suggesting that MRSA infection in poultry may be acquired from humans and may also spread from poultry to the workers at the same farm. Another study by Nworie et al. [71] in the Ebonyi State of Nigeria revealed that 24\% (78 of 325) of $325 \mathrm{~S}$. aureus isolates were from the clinics, and the percentage of carriage of MRSA was $15.3 \%$ in the clinics. All MRSA strains were MDR.

\section{Antibiotic Resistance}

$\beta$-Lactam antimicrobials, including cephalosporins and carbapenems (penicillin, oxacillin, cloxacillin, methicillin, flucloxacillin, and dicloxacillin), are the most commonly used antibiotics for the treatment of $S$. aureus [126-128]. S. aureus strains showed developed resistance to these antibiotics due to a plasmid-encoded penicillinase/ $\beta$-lactamase $[129,130]$. $\beta$-Lactamase is produced by $S$. aureus strains that have the bla gene. This enzyme deactivates $\beta$-lactam antibiotics through cleavage with the $\beta$-lactam ring $[131,132]$. In a large study by Lee [30], 1913 samples of feces, feed, milk, joint, uterus, trachea, and meat were collected from cattle, poultry, and pigs in Korea from May 2001 to April 2003 to detect the zoonotic potential of MRSA. Results showed that isolation of $421 \mathrm{~S}$. aureus strains as 28 isolates were resistant to $>2 \mu \mathrm{g} / \mathrm{mL}$ oxacillin. Moreover, 15 of 28 isolates were mecA positive. In Bangladesh, $S$. aureus strains isolated from newly hatched chicks and broiler and layer flocks [133] and frozen chicken rinse [134] showed $100 \%$ resistance to amoxicillin and ampicillin. In Upper Egypt, all $S$. aureus coagulase-positive isolates showed resistance to ampicillin, cefotaxime, and methicillin [73]. Besides, Morshdy et al. [135] found that $S$. aureus strains isolated from ready-to-eat food in Sharkia Province, Egypt, showed the highest resistance to both methicillin and cefotaxime (100\%), followed by amoxicillin (85.18\%). A recent study in India revealed that poultry litter isolates of $S$. aureus are $\beta$-lactamase producers and completely resistant to penicillin [38]. Moreover, Kemal et al. [97] detected high resistance to penicillin, ampicillin, and amoxicillin in $S$. aureus strains isolated from sold eggs in Eastern Ethiopia.

Resistance of $S$. aureus isolates, especially those from broiler chicken origin, to other classes of antimicrobials, such as fluoroquinolones, aminoglycosides, tetracyclines, and macrolides, has been reported [136,137]. Coagulase-positive $S$. aureus strains from live and slaughtered chickens showed $100 \%$ resistance to tetracycline, penicillin, and erythromycin [13]. In the Hail region of Saudi Arabia, $S$. aureus strains were isolated from 50 retail chicken meat samples at a percentage of $24 \%$, of which $25 \%$ resistance to tetracycline was found [138]. MRSA strains isolated from broilers and layers of chickens between 2009 and 2014 in Northern Algeria showed cross-resistance to aminoglycosides, fluoroquinolones, macrolides, sulfonamides, and tetracyclines [35]. However, recent studies emphasized that MRSA strains of animal origin showed more resistance to tetracycline, ciprofloxacin, and gentamicin than those isolated from human origin $[127,139]$.

In addition, vancomycin $[38,140]$ and inducible clindamycin [141] resistant $S$. aureus strains are increasingly demonstrated. In Northwest Algeria, vancomycin resistance has been detected in 54\% of poultry and $1.8 \%$ of human MRSA strains [110].

\section{Prevention and Control Strategies}

Sources of MRSA infections in humans and evidence to support animal-to-human transmission still need more investigations. Thus, molecular epidemiological studies concerning animal and human reservoirs, identifying the diversity of $S$. aureus and determining the antimicrobial susceptibility of S. aureus, are very important $[142,143]$. There is a great interest in detecting the diversity of MRSA in many settings. Animal-adapted clones may experience more host-adaptive evolutionary changes resulting in an epidemic spread of new and more virulent MRSA strains in the human population. Now, the most widely used molecular epidemiological techniques are Staphylococcus protein A gene typing and sequence types (ST). Different MRSA regional clones have been described in various countries worldwide. In Africa, existing clones of MRSA are replaced by many and new clonal identities from different countries. For instance, ST250-I [1B] was mainly associated with hospital-acquired infections in Ibadan, southwest Nigeria, and Ghana. ST8-IV [2B] was found in Cameroon, Angola, Ghana, Gabon, Nigeria, Madagascar, and South Africa, whereas ST8-II [2A] was only detected in South Africa [142]. Moreover, the small set of lineages and the clonal complex (CC) types (CC5, CC8, CC22, CC30, and CC48) are linked to most MRSA infection cases in hospitals. The whole-genome sequencing map revealed zoonotic transmission of MRSA harboring mecC $(\mathrm{CC} 130)$ in both animals and humans in Europe. However, the clinical importance of $m e c C$-positive MRSA is not yet clear in Africa. In addition, CC398 of MRSA of swine origin was closely related to those found in humans, different animal species, and meat products [143]. The community-associated (CC8) and hospital-associated (CC70) MRSA have been isolated from raw chicken, turkey, pork, and beef [143].

Regular monitoring of MRSA strains from poultry and livestock is necessary to understand the changes in the genetic selection and zoonotic potential of these resistant strains [94]. Monitoring of antimicrobial resistance is also essential to determine the effectiveness of new and antimicrobial generations.

To prevent MRSA infections, awareness, public health education, and good hygiene are critical, especially in veterinary medicine [144]. There is a great need for better sanitary education of food handlers 
to decrease their potential role as reservoirs and shedders of MRSA. In addition, hygienic measures should be taken into consideration to ensure the safety of food products, and a proper risk assessment should be applied to further clarify the possible health hazards for consumers. Parvin et al. [145] recommended the proper application of good manufacturing and hygiene practices and well-designed hazard analysis of a critical control point program in slaughterhouses and processing units to avoid contamination of poultry meat with MRSA.

Raising public awareness of the proper thermal processing and cooking of eggs, especially for immunocompromised individuals, such as pregnant women, children, and the elderly, is essential [64]. In addition, increasing the awareness of safe household rearing procedures of chicken as well as storage and handling of eggs is also crucial to prevent the dissemination of foodborne pathogens through the environment and the transfer of infection to other animals and humans [64].

The emergence of antibiotic resistance due to the indiscriminate use of antibiotics in poultry and animal farms can increase the difficulties of human treatment. The higher MRSA contamination of chicken products may be associated with antibiotics in bird husbandry [84]. Thus, it is better to use some classes of antimicrobials for animal disease treatment and other classes for human treatment [146].

The control and prevention of transmission of MRSA in healthcare facilities are also serious issues [147]. Patients after surgical operations, especially those who do not respond to antibiotic treatment, should consider possible MRSA infections. Suspected cases with MRSA should be kept under isolation conditions and subjected to bacteriological examination and antibiotic susceptibility testing before therapy. Special hygienic precautions and healthcare of contact persons should be considered with confirmed cases with MRSA infections. Controlling the possibility of zoonotic transmission should be through the cooperation between veterinary and medical professionals. Owners of animals should be advised by veterinarians about the possibility and risk of acquiring MRSA infections after contact with infected animals.

The WHO has developed a global action plan on antimicrobial resistance in collaboration with the Food and Agriculture Organization of the United Nations and the World Organization for Animal Health (OIE). On May 26, 2015, the World Assembly of Delegates of the OIE recommended the following: (1) Regular updating of the OIE list of antimicrobial agents of veterinary importance. (2) Annual data collection from OIE member countries to create a global database managed in parallel with the World Animal Health Information System. (3) Improvement of veterinary legislation and education of OIE member countries to facilitate the implementation of OIE and Codex Alimentarius guidelines related to antimicrobial resistance. (4) Regular surveillance of antimicrobialresistancewithdatacollectionontheuseof antimicrobial agents in food-producing animals. (5) OIE member countries should follow the guidance of the WHO global action plan on antimicrobial resistance with the support of OIE and WHO in the spirit of the "One Health" approach. (6) Strengthening the OIE collaboration with international organizations to combat counterfeit products. (7) Improvement of the rapid diagnostic tools to explore alternatives to antimicrobial use in animals, such as vaccine development.

\section{Conclusion}

The role of slaughterhouse workers in the spread of MRSA through the contamination of meat or handling contaminated meat and related products cannot be neglected. Accordingly, strict hygienic measures should be applied during food preparation; besides, strong legislation should be followed to produce food of high keeping quality. Workers in processing plants should wear special clothes and gloves during handling and processing of carcasses. Proper storage of retail carcasses is very important. In poultry farms, close-contact workers may be at high risk of MRSA infection and could be potential sources of community outbreaks. Thus, they should be careful and take all hygienic measures and precautions during the handling of live birds. Infected poultry flocks and their litter should be hygienically disposed.

The high prevalence of MRSA is alarming due to the significant public health consequence if the infection is transmitted to humans through the food chain. Therefore, continuous surveillance and monitoring of MDR $S$. aureus isolates are required to better define bacterial resistance to antimicrobial agents. A combined approach regarding the diagnosis and treatment of MRSA infection in humans and animals must be developed. The increase in antibiotic resistance among $S$. aureus isolates in poultry and human clinical cases call for caution in using these antibiotics. In addition, the link between antibiotic usage in animals and MRSA development should be paid more attention and the scientific community should be forced to follow and search for reservoirs of these resistant organisms.

\section{Authors' Contributions}

WAA: Collected the literature, drafted and revised the manuscript, and approved the final manuscript.

\section{Acknowledgments}

The author is thankful to Faculty of Veterinary Medicine, Cairo University, Egypt, for providing necessary facilities for this review. The author did not receive any funds for this study.

\section{Competing Interests}

The author declares that she has no competing interests. 


\section{Publisher's Note}

Veterinary World (Publisher of International Journal of One Health) remains neutral with regard to jurisdictional claims in published institutional affiliation.

\section{References}

1. Basset, P., Feil, E.J., Zanetti, G. and Blanc, D.S. (2011) The evolution and dynamics of methicillin-resistant Staphylococcus aureus. In: Tibayrenc, M., editor. Genetics and Evolution of Infectious Diseases. Elsevier, London. p669-676.

2. Cheung, G.Y.C., Bae, J.S. and Otto, M. (2021) Pathogenicity and virulence of Staphylococcus aureus. Virulence, 12(1): $547-569$.

3. Casey, A.L., Lambert, P.A. and Elliot, T.S.J. (2007) Staphylococci. Int. J. Antimicrob. Agents, 29(3): 23-32.

4. Olayinka, B.O., Bala, H.K., Ehinmidu, J.O. and Onaolapo, J.A. (2010) Multidrug-Resistant Staphylococcus aureus Isolates from Poultry Farms in Zaria, Nigeria. $14^{\text {th }}$ International Symposium on Staphylococci and Staphylococcal Infections, Bath, UK.

5. Abd El Tawab, A., Hofy, F.I., Mohamed, S.R. and Amin, S.H. (2017) Characterization of methicillin resistance Staphylococcus aureus isolated from chicken and human. Benha Vet. Med. J., 32(1): 132-137.

6. Bergmann, V., Kohler, B. and Vogel, K. (1980) Staphylococcus aureus infection in chickens in industrialized poultry units 1. Manifestations of Staphylococcus aureus infection in chickens. Arch. Exp. Vet. Med., 34(6): 891-903.

7. Achi, O. and Madubuike, C. (2007) Prevalence and antimicrobial resistance of Staphylococcus aureus isolated from retail ready to eat foods in Nigeria. Res. J. Microbiol., 2(6): 516-523.

8. Seo, K.S. and Bohach, G.A. (2003) Staphylococcus aureus. Ch 22 In: Doyle, M.P. and Beuchat, L.R., editors. Food Microbiology: Fundamentals and Frontiers. $3^{\text {rd }}$ ed. ASM Press, Washington, DC. p493-518.

9. Le Loir, Y., Baron, F. and Gautier, M. (2003) Staphylococcus aureus and food poisoning. Gen. Mol. Res., 2(1): 63-76.

10. Aydin, A., Sudagidan, M. and Muratoglu, K. (2011) Prevalence of staphylococcal enterotoxins, toxin genes and genetic-relatedness of foodborne Staphylococcus aureus strains isolated in the Marmara region of Turkey. Int. J. Food Microbiol., 148(2): 99-106.

11. Fitzgerald, J.R. (2012) Livestock-associated Staphylococcus aureus: Origin, evolution and public health threat. Trends Microbiol., 20(4): 192-198.

12. Witte, W. (1998) Medical consequences of antibiotic use in agriculture. Science, 279(5353): 996-997.

13. Otalu, O.J., Kabir, J., Okolocha, E.C. and Umoh, V.J. (2011) Multi-drug resistant coagulase-positive Staphylococcus aureus from live and slaughtered chickens in Zaria, Nigeria. Int. J. Poult. Sci., 10(11): 871-875.

14. Darwish, W.S., Atia, A.S., Reda, L.M., Elhelaly, A.E., Thompson, L.A. and Eldin, W.F.S. (2018) Chicken giblets and wastewater samples as possible sources of methicillin-resistant Staphylococcus aureus. Prevalence, enterotoxin production, and antibiotic susceptibility. J. Food Saf., 38(4): e12478.

15. Chan, C.X., Beiko, R.G. and Ragan, M.A. (2011) Lateral transfer of genes and gene fragments in Staphylococcus extends beyond mobile elements. J. Bacteriol., 193(15): 3964-3977.

16. Magiorakos, A.P., Srinivasan, A., Carey, R.B., Carmeli, Y., Falagas, M.E., Giske, C.G., Harbarth, S., Hindler, J.F., Kahlmeter, G., Olsson-Liljequist, B., Paterson, D.L., Rice, L.B., Stelling, J., Struelens, M.J., Vatopoulos, A.,
Weber, J.T. and Monnet, D.L. (2012) Multidrug-resistant, extensively drug-resistant and pan drug-resistant bacteria: An international expert proposal for interim standard definitions for acquired resistance. Clin. Microbiol. Infect., 18(3): 268-281.

17. Waters, A.E., Contente-Cuomo, T., Buchhagen, J., Liu, C.M., Watson, L., Pearce, K., Foster, J.T., Bowers, J., Driebe, E.M., Engelthaler, D.M., Keim, P.S. and Price, L.B. (2011) Multidrug-resistant Staphylococcus aureus in US meat and poultry. Clin. Infect. Dis., 52(10): 1227-1230.

18. Fluit, A.C. (2012) Livestock-associated Staphylococcus aureus. Clin. Microbiol. Infect., 18(8): 735-744.

19. Vengust, M., Anderson, M.E.C., Rousseau, J. and Weese, J.S. (2006) Methicillin-resistant staphylococcal colonization in clinically normal dogs and horses in the community. Lett. Appl. Microbiol., 43(6): 602-606.

20. Wu, S., Huang, J., Wu, Q., Zhang, J., Zhang, F., Yang, X., Wu, H., Zeng, H., Chen, M. and Ding, Y. (2018) Staphylococcus aureus isolated from retail meat and meat products in China: Incidence, antibiotic resistance and genetic diversity. Front. Microbiol., 9: 2767.

21. Abolghait, S.K., Fathi, A.G., Youssef, F.M. and Algammal, A.M. (2020) Methicillin-resistant Staphylococcus aureus (MRSA) isolated from chicken meat and giblets often produces staphylococcal enterotoxin $\mathrm{B}$ (SEB) in non-refrigerated raw chicken livers. Int. J. Food Microbiol., 328: 108669.

22. Okorie-Kanu, O.J., Anyanwu, M.U., Ezenduka, E.V., Mgbeahuruike, A.C., Thapaliya, D., Gerbig, G., Ugwuijem, E.E., OkorieKanu, C.O., Agbowo, P. and Olorunleke, S. (2020) Molecular epidemiology, genetic diversity and antimicrobial resistance of Staphylococcus aureus isolated from chicken and pig carcasses, and carcass handlers. PLoS One, 15: e0232913.

23. Kitai, S., Shimizu, A., Kawano, J., Sato, E., Nakano, C., Uji, T. and Kitagawa, H. (2005) Characterization of methicillin-resistant Staphylococcus aureus isolated from retail raw chicken meat in Japan. J. Vet. Med. Sci., 67(1): 107-110.

24. Kluytmans, J.A.J. (2010) Methicillin-resistant Staphylococcus aureus in food products: Cause for concern or case for complacency? Clin. Microbiol. Infect., 16(1): 11-15.

25. Rizek, C.F., Matté, M.H., Dropa, M., Mamizuka, E.M., de Almeida, L.M., Lincopan, N., Matté, G.R. and Germano, P.M. (2011) Identification of Staphylococcus aureus carrying the mecA gene in ready-to-eat food products sold in Brazil. Foodborne Pathog. Dis., 8(4): 561-563.

26. Schmithausen, R.M., Schulze-Geisthoevel, S.V., Heinemann, C., Bierbaum, G., Exner, M., Petersen, B. and Steinhoff-Wagner, J. (2018) Reservoirs and transmission pathways of resistant indicator bacteria in the biotope pig stable and along the food chain: A review from a one health perspective. Sustainability, 10(1): 3967.

27. Suleyman, G., Alangaden, G. and Bardossy A.C. (2018) The role of environmental contamination in the transmission of nosocomial pathogens and healthcare-associated infections. Curr. Infect. Dis. Rep., 20(6): 12.

28. Touimi, G.B., Bennani, L., Berrada, S., Moussa, B. and Bennani, B. (2020) Prevalence and antibiotic resistance profiles of Staphylococcus sp. isolated from food, food contact surfaces and food handlers in a Moroccan hospital kitchen. Lett. Appl. Microbiol., 70(4): 241-251.

29. Kinross, P., Petersen, A., Skov, R., Van Hauwermeiren, E., Pantosti, A., Laurent, F., Voss, A., Kluytmans, J., Struelens, M.J., Heuer, O. and Monnet, D.L. (2017) Livestock-associated methicillin-resistant Staphylococcus aureus (MRSA) among human MRSA isolates, European Union/European Economic Area countries, 2013. Euro Surveill., 22(44): 16-00696.

30. Adeyeye, J. and Adewale, A. (2013) Incidence of methicillin-resistant Staphylococcus aureus (MRSA) in a small 
poultry in South West, Nigeria. IOSR J. Agric. Vet. Sci., 5(3): 53-55.

31. Lee, J.H. (2003) Methicillin (oxacillin)-resistant Staphylococcus aureus strains isolated from major food animals and their potential transmission to humans. Appl. Environ. Microbiol., 69(11): 6489-6494.

32. World Health Organization. (2004) Developing and Maintaining Food Safety Control Systems for Africa: Current Status and Prospects for Change. In: Proceedings of the Second FAO/WHO Global Forum of Food Safety Regulators, Bangkok, Thailand, 12-14 October 2004, p12-14.

33. Scallan, E., Hoekstra, R.M., Angulo, F.J., Tauxe, R.V., Widdowson, M.A., Roy, S.L., Jones, J.L. and Griffin, P.M. (2011) Foodborne illness acquired in the United States Major pathogens. Emerg. Infect. Dis., 17(1): 7-15.

34. Sun, D.W. (2016) Handbook of Frozen Food Processing and Packaging. $2^{\text {nd }}$ ed. CRC Press, Boca Raton, FL, USA.

35. Bounar-Kechih, S., Taha Hamdi, M., Aggad, H., Meguenni, N. and Cantekin, Z. (2018) Carriage methicillin-resistant Staphylococcus aureus in poultry and cattle in Northern Algeria. Vet. Med. Int., 2018: 4636121.

36. Dhanarani, T.S., Shankar, C., Park, J., Dexilin, M., Kumar, R.R. and Thamaraiselvi, K. (2009) Study on acquisition of bacterial antibiotic resistance determinants in poultry litter. Poult. Sci., 88(7): 1381-1387.

37. Amoako, D.G., Somboro, A.M., King Abia, A.L., Allam, M., Ismail, A., Bester, L. and Essack, S.Y. (2019) Genomic analysis of methicillin-resistant Staphylococcus aureus isolated from poultry and occupational farm workers in Umgungundlovu District, South Africa. Sci. Total Environ., 670: 704-716.

38. Pugazhendhi, A., Michael, D., Prakash, D., Krishnamaurthy, P.P., Shanmuganathan, R., Al-Dhabi, N.A., Duraipandiyan, V., Arasu, M.V. and Kaliannan, T. (2020) Antibiogram and plasmid profiling of beta-lactamase producing multi-drug resistant Staphylococcus aureus isolated from poultry litter. J. King Saud Univ. Sci., 32(6): 2723-2727.

39. Behling, R.G., Eifert, J., Erickson, M.C., Gurtler, J.B., Kornacki, J.L., Line, E., Radcliff, R., Ryser, E.T., Stawich, B. and Van, Z. (2010) selected pathogens of concern to industrial food processors: Infectious, toxigenic, toxico-infectious, selected emerging pathogenic bacteria. In: Kornacki, J., editor. Principles of Microbiological Troubleshooting in the Industrial Food Processing Environment. Food Microbiology and Food Safety. Springer, New York.

40. Abubakar, U. and Sulaiman, S.A.S. (2018) Prevalence, trend and antimicrobial susceptibility of methicillin-resistant Staphylococcus aureus in Nigeria: A systematic review. J. Infect. Public Health, 11(6): 763-770.

41. Fessler, A.T., Kadlec, K., Hassel, M., Hauschild, T., Eidam, C., Ehricht, R., Monecke, S. and Schwarz, S. (2011) Characterization of methicillin-resistant Staphylococcus aureus isolates from food and food products of poultry origin in Germany. Appl. Environ. Microbiol., 77(20): 7151-7157.

42. Papadopoulos, P., Papadopoulos, T., Angelidis, A.S., Boukouvala, E., Zdragas, A., Papa, A., Hadjichristodoulou, C. and Sergelidis D (2018) Prevalence of Staphylococcus aureus and of methicillin-resistant S. aureus (MRSA) along the production chain of dairy products in North-Western Greece. Food Microbiol., 69: 43-50.

43. Gündoğan, N., Citak, S. and Turan, E. (2006) Slime production, DNase activity and antibiotic resistance of Staphylococcus aureus isolated from raw milk, pasteurized milk and ice cream samples. Food Control, 17(5): 389-392.

44. Neihart, R.E., Fried, J.S. and Hodges, G.R. (1988) Coagulase-positive staphylococci. South. Med. J., 81(4): 491-500.

45. Sanderson, H., Fricker, C., Brown, R.S., Majury, A. and Liss, S. (2016) Antibiotic resistance genes as an emerging environmental contaminant. Environ. Rev., 24: 205-218.

46. Atshan, S.S., Nor Shamsudin, M., Sekawi, Z., Lung, L.T., Hamat, R.A., Karunanidhi, A., Ali, A.M., GhaznaviRad, E., Ghasemzadeh-Moghaddam, H., Seng, J.S.C., Nathan, J.J. and Pei, C.P. (2012) Prevalence of adhesion and regulation of biofilm-related genes in different clones of Staphylococcus aureus. J. Biomed. Biotechnol., 2012: 976972.

47. Momtaz, H., Dehkordi, F.S., Rahimi, E., Asgarifar, A. and Momeni, M. (2013) Virulence genes and antimicrobial resistance profiles of Staphylococcus aureus isolated from chicken meat in Isfahan province, Iran. J. Appl. Poult. Res., 22(4): 913-921.

48. Foster, T.J., Geoghegan, J.A., Ganesh, V.K. and Hook, M. (2014) Adhesion, invasion and evasion: The many functions of the surface proteins of Staphylococcus aureus. Nat. Rev. Microbiol., 12(1): 49-62.

49. Murray, P.R., Rosenthal, K.S., Kobayashi, G.S. and Pfaller, M.A. (2002) Medical Microbiology. $4^{\text {th }}$ ed. Mosby, St. Louis, MO.

50. Malachowa, N. and DeLeo, F.R. (2010) Mobile genetic elements of Staphylococcus aureus. Cell. Mol. Life Sci., 67(18): 3057-3071.

51. Hartman, B.J. and Tomasz, A. (1986) Expression of methicillin resistance in heterogeneous strains of Staphylococcus aureus. Antimicrob. Agents Chemother., 29(1): 85-92.

52. Murakami, K., Nomura, K., Doi, M. and Yoshida, T. (1987) Production of low-affinity penicillin-binding protein by low-and high-resistance groups of methicillin-resistant Staphylococcus aureus. Antimicrob. Agents Chemother., 31(9): 1307-1311.

53. Song, M.D., Wachi, M., Doi, M., Ishino, F. and Matsuhashi, M. (1987) Evolution of an inducible penicillin-target protein in methicillin-resistant Staphylococcus aureus by gene fusion. FEBS Lett., 221(1): 167-171.

54. Ubukata, K., Yamashita, N. and Konno, M. (1985) Occurrence of a beta-lactam inducible penicillin-binding protein in methicillin-resistant Staphylococci. Antimicrob. Agents Chemother., 27(5): 851-857.

55. Berger-Barchi, B. (1995) Factors affecting methicillin resistance in Staphylococcus aureus. Int. J. Antimicrob. Agents, 6(1): 13-21.

56. Ito, T., Hiramatsu, K., Tomasz, A., de Lencastre, H., Perreten, V., Holden, M.T., Coleman, D.C., Goering, R., Giffard, P.M., Skov, R.L., Zhang, K., Westh, H., O’Brien, F., Tenover, F.C., Oliveira, D.C., Boyle-Vavra, S., Laurent, F., Kearns, A.M., Kreiswirth, B., Ko, K.S., Grundmann, H., Sollid, J.E., John, J.F. Jr., Daum, R., Soderquist, B. and Buist, G. (2012) Guidelines for reporting novel mecA gene homologues. Antimicrob. Agents Chemother., 56(10): 4997-4999.

57. Ito, T., Katayama, Y., Asada, K., Mori, N., Tsutsumimoto, K., Tiensasitorn, C. and Hiramatsu, K. (2001) Structural comparison of three types of staphylococcal cassette chromosome mec integrated in the chromosome in methicillin-resistant Staphylococcus aureus. Antimicrob. Agents Chemother., 45(5): 1323-1336.

58. Lowy, F.D. (2003) Antimicrobial resistance: The example of Staphylococcus aureus. J. Clin. Invest., 111(9): 1265-1273.

59. International Working Group on the Classification of Staphylococcal Cassette Chromosome Elements (IWGSCC). (2009) Classification of staphylococcal cassette chromosome mec ( $\mathrm{SCCmec}$ ): Guidelines for reporting novel SCCmec elements. Antimicrob. Agents Chemother., 53(12): 4961-4967.

60. Morshdy, A.M.A., Darwish, W.S., El-Dien, W.M.S. and Khalifa, S.M. (2018a) Prevalence of multidrug-resistant Staphylococcus aureus and Salmonella Enteritidis in meat products retailed in Zagazig city, Egypt. Slov. Vet. Res., 55(Suppl 20): 295-300.

61. Xing, X., Li. G., Zhang, W., Wang, X., Xia, X., Yang, B. and Meng, J. (2014) Prevalence, antimicrobial susceptibility, 
and enterotoxin gene detection of Staphylococcus aureus isolates in ready-to-eat foods in Shaanxi, People's republic of China. J. Food Prot., 77(2): 33-334.

62. Garcia-Alvarez, L., Holden, M.T., Lindsay, H., Webb, C.R., Brown, D.F., Curran, M.D., Walpole, E., Brooks, K., Pickard, D.J., Teale, C., Parkhill, J., Bentley, S.D., Edwards, G.F., Girvan, E.K., Kearns, A.M., Pichon, B., Hill, R.L., Larsen, A.R., Skov, R.L., Peacock, S.J., Maskell, D.J. and Holmes, M.A. (2011) Meticillin-resistant Staphylococcus aureus with a novel mecA homologue in human and bovine populations in the UK and Denmark: A descriptive study. Lancet Infect. Dis., 11(8): 595-603.

63. Islam, M.A., Parveen, S., Rahman, M., Huq, M., Nabi, A., Khan, Z.U.M., Ahmed, N. and Wagenaar, J.A. (2019) Occurrence and characterization of methicillin-resistant Staphylococcus aureus in processed raw foods and readyto-eat foods in an urban setting of a developing country. Front. Microbiol., 10: 503.

64. Eid, S., Nasef, S.A. and Erfan, A.M. (2015) Multidrugresistant bacterial pathogens in eggs collected from backyard chickens. Assiut Vet. Med. J., 61(144): 87-103.

65. Holmberg, S.D. and Blake, P.A. (1984) Staphylococcal food poisoning in the United States. New facts and old misconceptions. J. Am. Med. Assoc., 251(4): 487-489.

66. Dickinson, M. and Bisno, A.L. (1993) Infections associated with prosthetic devices: Clinical considerations. Int. J. Artif. Organs, 16(11): 749-754.

67. Sawai, T., Tomono, K., Yanagihara, K., Yamamato, Y., Kaku, M., Hirakata, Y., Koga, H., Tashiro, T. and Kohno, S. (1997) Role of coagulase in a murine model of hematogenous pulmonary infection induced by intravenous injection of Staphylococcus aureus enmeshed in agar beads. Infect. Immun., 65(2): 466-471.

68. Abdalrahman, L.S., Stanley, A., Wells, H. and Fakhr, M.K. (2015) Isolation, virulence, and antimicrobial resistance of methicillin-resistant Staphylococcus aureus (MRSA) and methicillin-sensitive Staphylococcus aureus (MSSA) strains from Oklahoma retail poultry meats. Int. J. Environ. Res. Public Health, 12(6): 6148-6161.

69. Mamza, S.A., Egwu, G.O. and Mshelia, G.D. (2010) Antibiotic susceptibility patterns of beta-lactamase-producing Escherichia coli and Staphylococcus aureus isolated from chickens in Maiduguri (Arid zone), Nigeria. Vet. Arch., 80(2): 283-297.

70. Suleiman, A., Zaria, L.T., Grema, H.A. and Ahmadu, P. (2013) Antimicrobial-resistant coagulase-positive Staphylococcus aureus from chickens in Maiduguri, Nigeria. Sokoto J. Vet. Sci., 11(1): 51-55.

71. Nworie, A., Elom, M.O., Gideon, I.A., Azi, S.O., Okekpa, S.I., Ukwah, B.N., Usanga, V.U., Okon, U.N., Chinwe, E., Olayinka, B.O., Onaolapo, J.A. and Ehinmidu, J.O. (2016) Multi-drug resistant Staphylococcus aureus from poultry farms in Ebonyi state, Nigeria. Int. J. Microbiol. Gen. Mol. Biol. Res., 2(3): 1-11.

72. Ali, Y., Islam, A., Muzahid, N.H., Sikder, O.F., Hossain, A. and Marzan, L.W. (2017) Characterization, prevalence and antibiogram study of Staphylococcus aureus in poultry. Asian Pac. J. Trop. Biomed., 7(3): 253-256.

73. Bakheet, A.A., Amen, O., Habaty, S.H. and Darwish, S.F. (2018) Prevalence of Staphylococcus aureus in broiler chickens with special reference to beta-lactam resistance genes in the isolated strains. Alex. J. Vet. Sci., 57(2): 25-33.

74. Nworie, A., Onyema, A.S., Okekpa, S.I., Elom, M.O., Umoh, N.O., Usanga, V.U., Ibiam, G.A., Ukwah, B.N., Nwadi, L.C., Ezeruigbo, C., Olayinka, B.O., Ehinmidu, J.O., Onaolapo, J.A., Hanson, B.M., Wardyn, S.E. and Smith, T.C. (2017) A novel methicillin-resistant Staphylococcus aureus t11469 and a poultry endemic strain t002 (ST5) are present in chicken in Ebonyi State, Nigeria. Biomed. Res. Int., 2017: 2936461.

75. Abdulrahman, H.I., Geidam, Y.A., Abubakar, M.B., Gashua, M.M., Gulani, I.A. and Galadima, H.B.
(2018) Phenotypic detection and antibiogram of Staphylococcus aureus from poultry processing units in Maiduguri, Borno State, Nigeria. Asian J. Res. Anim. Vet. Sci., 1(1): 1-8.

76. Ayeni, F.A., Ruppitsch, W. and Allerberger, F. (2018) Molecular characterization of clonal lineages and staphylococcal toxin genes from $S$. aureus in Southern Nigeria. Peer J., 6: e5204.

77. Persoons, D., Van Hoorebeke, S., Hermans, K., Butaye, P., de Kruif, A., Haesebrouck, F. and Dewulf, J. (2009) Methicillin-resistant Staphylococcus aureus in poultry. Emerg. Infect. Dis., 15(3): 452-453.

78. Liu, D., Chai, T., Xia, X., Gao, Y., Cai, Y., Li, X., Miao, Z., Sun, L., Hao, H., Roesler, U. and Wang, J. (2012) Formation and transmission of Staphylococcus aureus (including MRSA) aerosols carrying antibiotic-resistant genes in a poultry farming environment. Sci. Total Environ., 426: 139-145.

79. Geenen, P.L., Graat, E.A.M., Haenen, A., Hengeveld, P.D., Van Hoek, A.H.A.M., Huijsdens, X.W., Kappert, C.C., Lammers, G.A.C., Van Duijkeren, E. and Van De Giessen, A.W. (2013) Prevalence of livestock-associated MRSA on Dutch broiler farms and in people living and/or working on these farms. Epidemiol. Infect., 141(5): 1099-1108.

80. Friese, A., Schulz, J., Zimmermann, K., Tenhagen, B.A., Fetsch, A., Hartung, J. and Röslera, U. (2013) Occurrence of livestock-associated methicillin-resistant Staphylococcus aureus in Turkey and broiler barns and contamination of air and soil surfaces in their vicinity. Appl. Environ. Microbiol., 79(8): 2759-2766.

81. Karmi, M. (2013) Prevalence of methicillin-resistant Staphylococcus aureus in poultry meat in Qena, Egypt. Vet. World, 6(10): 711-715.

82. Benrabia, I., Hamdi, T.M., Shehata, A.A., Neubauer, H. and Wareth, G. (2020) Methicillin-resistant Staphylococcus aureus (MRSA) in poultry species in Algeria: Long-term study on prevalence and antimicrobial resistance. Vet. Sci., 7(2): 54.

83. Datta, S., Akter, A., Shah, I., Fatema, K., Islam, T., Bandyopadhyay, A., Khan, Z. and Biswas, D. (2012) Microbiological quality assessment of raw meat and meat products, and antibiotic susceptibility of isolated Staphylococcus aureus. Agric. Food Anal. Bacteriol., 2(3): 187-194.

84. De Boer, E., Zwartkruis-Nahuis, J.T., Wit, B., Huijsdens, X.W., de Neeling, A.J., Bosch, T., van Oosterom, R.A., Vila, A. and Heuvelink, A.E. (2009) Prevalence of methicillin-resistant Staphylococcus aureus in meat. Int. J. Food Microbiol., 134(1-2): 52-56.

85. Kwon, N.H., Park, K.T., Jung, W.K., Youn, H.Y., Lee, Y., Kim, S.H., Bae, W., Lim, J.Y., Kim, J.Y., Kim, J.M., Hong, S.K. and Park, Y.H. (2016) Characteristics of methicillin-resistant Staphylococcus aureus isolated from chicken meat and hospitalized dogs in Korea and their epidemiological relatedness. Vet. Microbiol., 117(2-4): 304-312.

86. Gündoğan, N., Citak, S., Yucel, N. and Devren, A. (2005) A note on the incidence and antibiotic resistance of Staphylococcus aureus isolated from meat and chicken samples. Meat Sci., 69(4): 807-810.

87. Fox, A., Pichon, B., Wilkinson, H., Doumith, M., Hill, R.L.R., McLauchlin, J. and Kearns, A.M. (2017) Detection and molecular characterization of livestock-associated MRSA in raw meat on retail sale in North West England. Lett. Appl. Microbiol., 64(3): 239-245.

88. Tang, Y., Larsen, J., Kjeldgaard, J., Andersen, P.S., Skov, R. and Ingmer, H (2017) Methicillin-resistant and-susceptible Staphylococcus aureus from retail meat in Denmark. Int. J. Food Microbiol., 249: 72-76.

89. Rahman,M.A., Rahman,A.K.M., Islam,M.A. andAlam, M.M. (2018) Multidrug-resistant Staphylococcus aureus isolated from milk, chicken meat, beef and egg in Bangladesh. Res. 
Agric. Livest. Fish., 5(2): 175-183.

90. Akhi, M.A., Das, N.C., Banik, A., Abony, M., Juthi, M. and Uddin, M.E. (2019) Detection of drug-resistant $S$. aureus from poultry samples collected from different areas of Bangladesh. Microbiol. Res. J. Int., 29(1): 1-10.

91. Morshdy, A.M.A., Hussein, M.A., Tharwat, A.E. and Fakhry, B.A. (2018b) Prevalence of enterotoxigenic and multi-drug resistant Staphylococcus aureus in ready to eat meat sandwiches. Slov. Vet. Res., 55(Suppl 20): 367-374.

92. Pondit, A., Haque, Z.F., Sabuj, A.A.M., Khan, M.S.R. and Saha, S. (2018) Characterization of Staphylococcus aureus isolated from chicken and quail eggshell. J. Adv. Vet. Anim. Res., 5(4): 466-471.

93. Saadati, A., Mashak, Z. and Yarmand, M.S. (2019) Prevalence of staphylococcal cassette chromosome mec and panton-valentine leukocidin gene amongst the methicillin-resistant Staphylococcus aureus strains isolated from fowl meat. Int. J. Ent. Pathog., 7(3): 93-98.

94. Silva, V., Vieira-Pinto, M., Saraiva, C., Manageiro, V., Reis, L., Ferreira, E., Caniça, M., Capelo, J.L., Igrejas, G. and Poeta, P. (2021) Prevalence and characteristics of multidrug-resistant livestock-associated methicillin-resistant Staphylococcus aureus (LA-MRSA) CC398 isolated from quails (Coturnix coturnix japonica) slaughtered for human consumption. Animals, 11(7): 2038.

95. Saadati, A., Mashak, Z. and Yarmand, M.S. (2021) Prevalence and molecular characterization of enterotoxin and antibiotic resistance encoding genes in the methicillin-resistant Staphylococcus aureus recovered from poultry meat. Egypt. J. Vet. Sci., 52(2): 163-173.

96. Stepień-Pyśniak, D., Marek, A. and Rzedzicki, J. (2009) Occurrence of bacteria of the genus Staphylococcus in table eggs descended from different sources. Pol. J. Vet. Sci., 12(4): 481-484.

97. Kemal, J., Beji, W. and Tesfamariam, G. (2021) Occurrence and evaluation of antimicrobial susceptibility of Staphylococcus aureus isolated from chicken eggs, Eastern Ethiopia. J. Bacteriol. Parasitol., S9: 3.

98. Boyce, J.M. (1998) Are the epidemiology and microbiology of methicillin-resistant Staphylococcus aureus changing? J. Am. Med. Assoc., 279(8): 623-624.

99. Mitchell, J.M., MacCulloch, D. and Morris, A.J. (1996) MRSA in the community. N. Z. Med. J., 109(1032): 411.

100. Van Cleef, B.A.G., Broens, E.M., Voss, A., Huijsdens, X.W., Zuchner, L., Van Benthem, B.H.B., Kluytmans, J.A.J., Mulders, M.N. and Van De Giessen, A.W. (2010) High prevalence of nasal MRSA carriage in slaughterhouse workers in contact with live pigs in the Netherlands. Epidemiol. Infect., 138(5): 756-763.

101. Rafee, Y., Abde-Haq, N., Asmar, B., Salimnia, T., Pharm, V.C., Pharm, M.J.R. and Amjad, M. (2012) Increased prevalence of methicillin-resistant Staphylococcus aureus nasal colonization in household contacts of children with community-acquired disease. BMC Infect. Dis., 12: 45.

102. Hafiz, S., Hafiz, A.N., Ali, L., Chughtai, A.S., Memon, B., Ahmed, A., Hussain, S., Sarwar, G., Mughal, T., Awan, A., Zaki, K. and Fareed, A. (2002) Methicillin-resistant Staphylococcus aureus: A multicentre study. J. Pak. Med. Assoc., 52(7): 31-32.

103. Kesah, C., Ben Redjeb, S., Odugbemi, T.O., Boye, C.S., Dosso, M., Ndinya Achola, J.O., Koulla-Shiro, S., Benbachir, M., Rahal, K. and Borg, M. (2003) Prevalence of methicillin-resistant Staphylococcus aureus in eight African hospitals and Malta. Clin. Microbiol. Infect., 9(2): 153-156.

104. Ghebremedhin, B., Olugbosi, M.O., Raji, A.M., Layer, F., Bakare, R.A., Kong, B. and Konig, W. (2009) Emergence of a community-associated methicillin resistance profile in Southwest Nigeria. J. Clin. Microbiol., 47(9): 2975-2980.

105. Okesola, A.O., Oni, A.A. and Bakare, R.A. (1999) Nosocomial infections: Methicillin-resistant Staphylococcus aureus in wound infection in Ibadan, Nigeria. Afr. J. Med. Sci., 28(1-2): 55-57.
106. Sina, H., Baba-Moussa, F., Ahoyo, T.A., Mousse, W., Anagonou, S., Gbenou, J.D., Prevost, G., Kotochoni, S.O. and Baba-Moussa, L. (2011) Antibiotic susceptibility and toxins production of Staphylococcus aureus isolated from clinical samples from Benin. Afr. J. Microbiol. Res., 5(18): 2797-2803.

107. Adegoke, A.A. and Komolafe, A.O. (2009) Multidrugresistant Staphylococcus aureus in clinical cases in Ile-Ife, Southwest Nigeria. Int. J. Med. Med. Sci., 1(3): 68-72.

108. Ramdani-Bouguessa, N., Bes, M., Meugnier, H., Forey, F., Reverdy, M.E., Lina, G., Vandenesch, F., Tazir, M. and Etienne, J. (2006) Detection of methicillin-resistant Staphylococcus aureus strains resistant to multiple antibiotics and carrying the Panton-Valentine leukocidin genes in an Algiers hospital. Antimicrob. Agents Chemother., 50(3): 1083-1085.

109. Antri, K., Rouzic, N., Dauwalder, O., Boubekri, I., Bes, M., Lina, G., Vandenesch, F., Tazir, M., Ramdani-Bouguessa, N. and Etienne, J. (2011) High prevalence of methicillin-resistant Staphylococcus aureus clone ST80-IV in hospital and community settings in Algiers. Clin. Microbiol. Infect., 17(4): 526-532.

110. Rebiahi, S.A., Abdelouahid, D.E., Rahmoun, M., Abdelali, S. and Azzaoui, H. (2011) Emergence of vancomycin-resistant Staphylococcus aureus identified in the Tlemcen university hospital (Northwest Algeria). Med. Infect. Dis., 41(12): 646-651.

111. European Centre for Disease Prevention and Control. (2011) Antimicrobial Resistance Surveillance in Europe 2010. Annual Report of the European Antimicrobial Resistance Surveillance Network (EARS-Net). ECDC, Stockholm. Available from: https://www.ecdc.europa. eu/en/publications-data/antimicrobial-resistance-surveillance-europe-2010\#no-link. Retrieved on 17-11-2021.

112. Dantes, R., Mu, Y., Belflower, R., Aragon, D., Dumyati, G., Harrison, L.H., Lessa, F.C., Lynfield, R., Nadle, J., Petit, S., Ray, S.M., Schaffner, W., Townes, J. and Fridkin, S. (2013) National burden of invasive methicillin-resistant Staphylococcus aureus infections, United States, 2011. JAMA Int. Med., 173(21): 1970-1978.

113. You, J.H.S., Choi, K.W., Wong, T.Y., Ip, M., Ming, W.K., Wong, R.Y., Chan, S.N., Tse, H.T., Chau, C.T.S. and Lee, N.L.S. (2017) Disease burden, characteristics, and outcomes of methicillin-resistant Staphylococcus aureus bloodstream infection in Hong Kong. Asian Pac. J. Public Health, 29(5): 451-461.

114. Wei-Wei, L.I., Zhu, J.H., Zhen, S.Q., Liang, X.C., Jiang, Y.Y. and Ning, L.I. (2018) Analysis of foodborne disease outbreaks in China mainland in 2011. Chinese J. Food Hygiene, 30: 283-288.

115. Huijsdens, X.W., van Dijke, B.J., Spalburg, E., van SantenVerheuvel, M.G., Heck, M.E.O., Pluister, G.N., Voss, A., Wannet, W.J.B. and de Neeling, A.J. (2006) Communityacquired MRSA and pig-farming. Ann. Clin. Microbiol. Antimicrob., 5: 26.

116. de Sousa, M.A. (2017) MRSA among animals: Current overview. Clin. Microbiol. Infect., 23(6): 373-380.

117. Mulders, M.N., Haenen, A.P., Geenen, P.L., Vesseur, P.C., Poldervaart, E.S., Bosch, T., Huijsdens, X.W., Hengeveld, P.D., Dam-Deisz, W.D., Graat, E.A., Mevius, D., Voss, A. and Van De Giessen, A.W. (2010) Prevalence of livestock-associated MRSA in broiler flocks and risk factors for slaughterhouse personnel in the Netherlands. Epidemiol. Infect., 138(5): 743-755.

118. Odetokun, I.A., Ballhausen, B., Adetunji, V.O., GhaliMohammed, I., Adelowo, M.T., Adetunji, S.A. and Fetsch, A. (2018) Staphylococcus aureus in two municipal abattoirs in Nigeria: Risk perception, spread and public health implications. Vet. Microbiol., 216: 52-59.

119. Momoh, A.H., Kwaga, J.K.P., Bello, M., Sackey, A.K.B. and Larsen, A.R. (2018) Antibiotic resistance and molecular characteristics of Staphylococcus aureus isolated from 
backyard-raised pigs and pig workers. Trop. Anim. Health Prod., 50(7): 1565-1571.

120. Stewart-Johnson, A., Dziva, F., Abdela, W., Rahaman, S. and Adesiyun, A. (2019) Prevalence of methicillin-resistant Staphylococcus aureus in broilers and workers at "pluck shops" in Trinidad. Trop. Anim. Health Prod., 51(2): 369-372.

121. Dehkordi, F.S., Gandomi, H., Basti, A.A., Misaghi, A. and Rahimi, E. (2017) Phenotypic and genotypic characterization of antibiotic resistance of methicillin-resistant Staphylococcus aureus isolated from hospital food. Antimicrob. Resist. Infect. Control, 6: 104.

122. Horan, T., Culver, D., Jarvis, W., Emori, G., Banerjee, S., Martone, W. and Thornsberry, C. (1988) Pathogens causing nosocomial infections: Preliminary data from the national nosocomial infections surveillance system. Antimicrobic Newsletter, 5(9): 65-67.

123. Boucher, H.W. and Corey, G.R. (2008) Epidemiology of methicillin-resistant Staphylococcus aureus. Clin. Infect. Dis., 46(5): S344-S349.

124. Zetola, N., Francis, J.S., Nuermberger, E. and Bishai, W. (2005) Community-acquired methicillin-resistant Staphylococcus aureus: An emerging threat. Lancet Infect. Dis., 5(5): 275-286.

125. Van Loo, I., Huijsdens X. and Tiemersma, E. (2007) Emergence of methicillin-resistant Staphylococcus aureus of animal origin in humans. Emerg. Infect. Dis., 13(12): 1834-1839.

126. Andreoletti, O., Budka, H., Buncic, S., Colin, P., Collins, J.D., De, A., Noeckler, B.N., Maradona, M.P., Roberts, T. and Vågsholm, I. (2009) Assessment of the public health significance of meticillin-resistant Staphylococcus aureus (MRSA) in animals and foods. EFSA J., 993: 1-73.

127. Jayaweera, J.A.A. and Kumbukgolla, W.W. (2017) Antibiotic resistance patterns of methicillin-resistant Staphylococcus aureus (MRSA) isolated from livestock and associated farmers in Anuradhapura, Sri Lanka. Germs, 7(3): 132-139.

128. Watkins, R.R., Holubar, M. and David, M.Z. (2019) Antimicrobial resistance in methicillin-resistant Staphylococcus aureus to newer antimicrobial agents. Antimicrob. Agents Chemother., 63(12): e1216-19.

129. Salimnia, H. and Brown, W. (2005) Detection of Oxacillin Resistance in Staphylococcus aureus: Comparison of Phoenix Oxacillin and Cefoxitin MICs, Microscan Oxacillin MIC, Oxacillin and Cefoxitin Disk Diffusion, and mecA Gene Detection. Interscience Conference on Antimicrobial Agents and Chemotherapy (ICAAC), 12-20. Available from: https://legacy.bd.com/ds/technicalCenter/ whitepapers/lr222305.pdf. Retrieved on 17-11-2021.

130. Babic, M., Hujer, A.M. and Bonomo, R.A. (2006) What's new in antibiotic resistance? Focus on beta-lactamases. Drug Resist. Updat., 9(3): 142-156.

131. Giannoudis, P.V., Parker, J. and Wilcox, M.H. (2005) Methicillin-resistant Staphylococcus aureus in trauma and orthopaedic practice. Bone Joint J., 87(6): 749-754.

132. Kiliç, E. and Çirak, M.Y. (2006) Comparison of staphylococcal beta-lactamase detection methods. FABAD J. Pharm. Sci., 31(2): 79-84.

133. Shahjada, Z., Hussain, K., Islam, M.M., Majumder, S., Hasan, I., Rahman, M. and Saha, S. (2017) Bacteria causing omphalitis in newly hatched chicks from broiler and layer flocks and their antibiotic profiles. Int. J. Nat. Soc. Sci.,
4(2): $73-81$.

134. Islam, N.N., Akter, M., Farzana, Z., Kader, A.J.B., Uddin, I., Siddiki, A. and Kamaruddin, K. (2014) Detection of Staphylococcus aureus in frozen chicken rinse through bacteriological and Nuc gene-specific PCR methods and their drug resistance patterns in Southern Chittagong, Bangladesh. Res. J. Microbiol., 9(5): 251-264.

135. Morshdy, A.E.M., Hussein, M.A., Merwad, A.M.A, Hanan, E.M. and Mohamed, A.H. (2019) Phenotypic, genotypic resistance and virulotyping of Staphylococcus aureus isolated from ready-to-eat food in Egypt. Adv. Anim. Vet. Sci., 7(s2): 63-70.

136. Nemati, M., Hermans, K., Lipinska, U., Denis, O., Deplano, A., Struelens, M., Devriese, L.A., Pasmans, F. and Haesebrouck, F. (2008) Antimicrobial resistance of old and recent Staphylococcus aureus isolates from poultry: First detection of livestock-associated methicillin-resistant strain ST398. Antimicrob. Agents Chemother., 52(10): 3817-3819.

137. Delorme, T., Rose, S., Senita, J., Callahan, C. and Nasr, P. (2009) Epidemiology and susceptibilities of methicillin-resistant Staphylococcus aureus in Northeastern Ohio. Am. J. Clin. Pathol., 132(5): 668-677.

138. Elabbasy, M.T. and Morshdy, A.M. (2015) Studies on retail chicken meats with a special reference to antibiotic-resistant bacteria. Suez Canal Vet. Med. J., 20(2): 271-279.

139. Bernier-Lachance, J., Arsenault, J., Usongo, V., Parent, É., Labrie, J., Jacques, M., Malouin, F. and Archambault, M. (2020) Prevalence and characteristics of livestock-associated methicillin-resistant Staphylococcus aureus (LA-MRSA) isolated from chicken meat in the province of Quebec, Canada. PLoS One, 15(1): e0227183.

140. McGuinness, W.A., Malachowa, N. and DeLeo, F.R. (2017) Vancomycin-resistance in Staphylococcus aureus. Yale J. Biol. Med., 90(2): 269-281.

141. Stryjewski, M.E. and Corey, G.R. (2014) Methicillinresistant Staphylococcus aureus: An evolving pathogen. Clin. Infect. Dis., 58(1): 10-19.

142. Abdulgader, S.M., Shittu, A.O., Nicol, M.P. and Kaba, M. (2015) Molecular epidemiology of methicillin-resistant Staphylococcus aureus in Africa: A systematic review. Front. Microbiol., 6: 348.

143. Thapaliya, D., Forshey, B.M., Kadariya, J., Quick, M.K., Farina, S., O’Brien, A., Nair, R., Nworie, A., Hanson, B., Kates, A., Wardyn, S. and Smith, T.C. (2017) Prevalence and molecular characterization of Staphylococcus aureus in commercially available meat over a one-year period in Iowa, USA. Food Microbiol., 65: 122-129.

144. Morgan, M. (2008) Methicillin-resistant Staphylococcus aureus and animals: Zoonosis or humanosis? J. Antimicrob. Chemother., 62(6): 1181-1187.

145. Parvin, M.S., Ali, M.Y., Talukder, S., Nahar, A., Chowdhury, E.H., Rahman, M.T. and Islam, M.T. (2021) Prevalence and multi-drug resistance pattern of methicillin-resistant $S$. aureus isolated from frozen chicken meat in Bangladesh. Microorganisms, 9(3): 636.

146. Darwish, W.S., Eldaly, E.A., ElAbbasy, M.T., Ikenaka, Y., Nakayama, S. and Ishizuka, M. (2013) Antibiotic residues in food: The African scenario. Jpn. Vet. Res., 61(Suppl 1): S13-S22.

147. Coia, J.E., Duckworth, G.J., Edwards, D.I., Farrington, M., Fry, C., Humphreys, H., Mallaghan, C. and Tucker, D.R. (2006) Guidelines for the control and prevention of methicillin-resistant Staphylococcus aureus (MRSA) in healthcare facilities. J. Hosp. Infect., 63(1): S1-44.

\section{$* * * * * * * *$}

